\title{
Baltijas zinātṇu vēstures konferences pusgadsimta gaitā: no Hruščova līdz Ilvesam (1958-2008)
}

(Ievadlekcija 23. Starptautiskajā Baltijas zinātṇu vēstures konferencē Rīgā, RTU, 2008. g. 9. oktobrī.)

\section{Jānis Stradiņ̌̌}

2008. gads ir pārbagāts, vismaz Latvijā, ar dažādām jubilejām, gan izcilām gadareizēm, gan šaurākam lokam nozīmīgām. Saprotams, visas trīs Baltijas valstis svin sava valstiskuma iedibināšanas 90 gadus, tas mums ir galvenais, taču Lietuva nesen atzīmējusi Lietuvju Zinātņu biedrības 100 gadus, Igaunija - savas Zinātṇu akadēmijas 70 gadus, Latvija - ortogrāfijas reformas (latīniskās ortogrāfijas akceptēšanas) 100 gadus. 23. Baltijas Zinātṇu vēstures starptautiskajā konferencē svarīgi ir atcerēties, ka šogad aprit tieši 50 gadu kopš šiss tradīcijas iedibināšanas, ka 1958. gada jūnijā Rīgā notika pirmais šāda veida saiets. Šì konference un zinātṇu vēsturnieku kolektīvs, kas pamazām sāka veidoties [1], bija organizētas un koordinētas zinātṇu vēstures pētniecỉbas sākums Baltijā (sk. 254. lpp. 1. pielikumā kopējs visu konferenču saraksts un tematika).

Toreizējos vēstures apstākḷos pirmā konference (apspriede) nepavisam nebija ne viegls, ne ordinārs saiets. Stạlina režīma gados PSRS zinātne bija stingri izolējusies no pasaules zinātnes, vairākās nozarēs bija sazēlušas nezinātniskas, pat tumsonīgas pieejas, tādas kā T. Lisenko "mičuriniskā biolog̣ija", O. Lepešinskas "jaunā mācība par šūnu", marksistiski motivēta vulgāra vēršanās pret kvantu fiziku, Einšteina teoriju, kibernētiku u. tml. Lai pretotos Rietumu itin kā kaitīgajai ietekmei, bija uzsākta cinna pret "kosmopolītismu" un "zemošanos Rietumu priekšā", nepamatoti noniecināti Eiropas zinātnes sasniegumi un mērḳtiecīgi veicināti krievu zinātnieku un inženieru apšaubāmas "prioritātes" meklējumi visās jomās [2]. İpaši pèc 2. Pasaules kara nonievāja uzvarēto vāciešu nopelnus zinātnes attīstībā, pie reizes arī Baltijas vāciešus (Krievijas impērijas pavalstniekus!), kurus vai nu noklusēja un nopulgoja, vai pasludināja par krieviem, kā, piemēram, K. M. Bēru. Valdošās nostādnes tika ieturētas lielkrievu šovinisma garā, lielā mērā ignorējot 


\section{J. Stradinš}

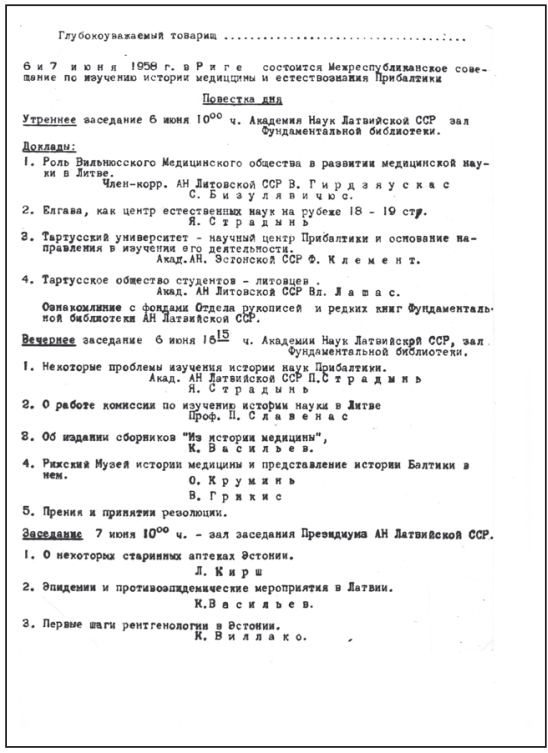

P. Stradiṇa organizētās Starprepublikāniskās apspriedes par Baltijas medicinas un dabaszinātṇu vēstures izpēti (1. Baltijas Dabaszinātnu vēstures konferences) ielūgums un darba kārtība 1958. g. 1.-7. jūnijā, Rīgā

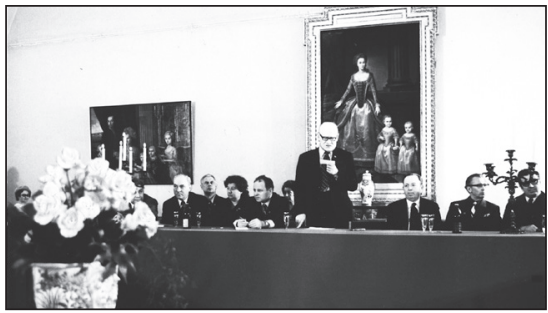

10. Baltijas Zinātñu vēstures konferences izbraukuma sesija Jelgavā, kas veltīta Jelgavas Pētera akadēmijas 200 gadu jubilejai (1975. g. 23. aprīīi). No kreisās: Latv. PSR Kultūras ministrs V. Kaupužs, Jelgavas partijas komitejas sekretāre, akad. J. Stradiņš, akad. P. Valeskalns, PSRZ ZA Dabaszinātṇu un tehnikas vēstures institūta direktora vietnieks A. Fjodorovs (Maskava), prof. K. Vasiljevs (Odesa), Dr. A. Šamins (Maskava)

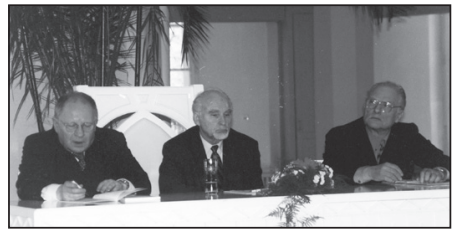

20. Baltijas Zinātṇu vēstures konferences prezidijā no labās - akad. J. Stradiňš, Igaunijas Zinātṇu vēstures asociācijas prezidents akad. K. Sīlivasks, Lietuvas Zinātnu vēstures asociācijas prezidents J. A. Krikštopaitis (Tartu, 2001. g. 30. janv.)

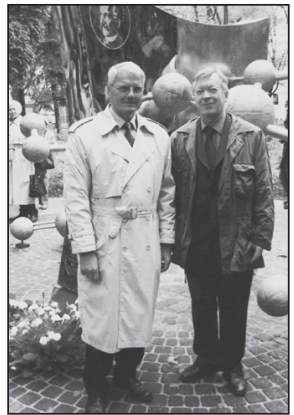

RTU rektors akad. I. Knēts (no labās) un P. Valdena mazdēls, Somijas ZA īstenais loceklis prof. E. Hollo (Helsinki) 21. Baltijas Zinātṇu vēstures konferences ietvaros 2003. g. 15. oktobrī, P. Valdena piemiṇas zīmi Rīgā atklājot

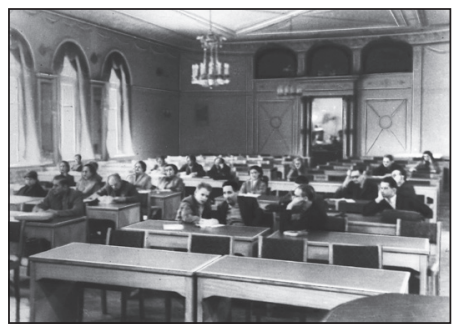

1. Baltijas konferences noslēguma sēdē Latv. PSR ZA Konferenču zālē (tag. Vāgnera zālē), Rīgā 


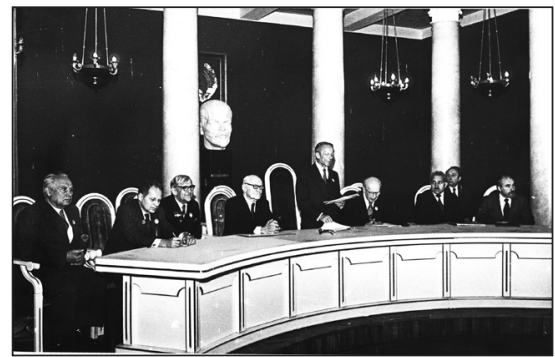

12. Baltijas Zinātṇu vēstures konference, veltita Vilñas Universitātes 400 gadu jubilejai (Vilnnāa, 1979. g. oktobrī). No kreisās: S. Bizjulēvičs (Viḷna), akad. J. Stradiňš, Baltkrievijas PSR ZA akadēmikisis M. Eljaševičs, akad. P. Valeskalns, Lietuvas PSR ZA akad., Viḷnas Universitātes rektors J. Kubilus, Lietuvas PSR ZA akad. P. Slavens, PSRS Dabaszinātñu un tehnikas vēsturnieku nacionālās apvienības sekretārs V. Sokoḷskis, Igaunijas PSR ZA akad. K. Silivasks

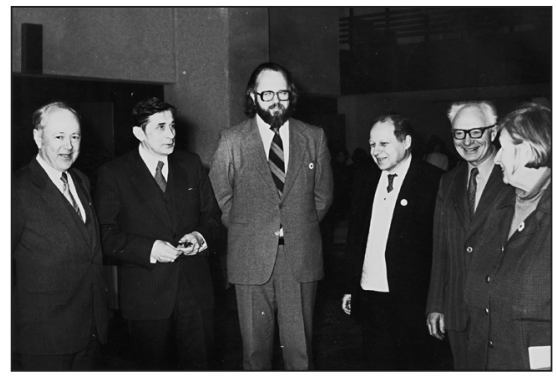

Kr. Barona 150 gadu jubilejai veltitais simpozijs par paleozinātni 1985. g. Jūrmalā. No kreisās: doc. J. Klētnieks, H. Ellsalu (Igaunija), Dainis Stalts, akad. J. Stradin̄š, Konstantīns Karulis, E. Šimkunaite (Lietuva). Simpozijs notika 14. konferences ietvaros, tajā pirmoreiz iztirzāja senāko zinātnes (arī medicīnas) priekšstatu veidošanos pēc folkloras un arheolog̣ijas datiem, ìpaši paleoastronomijas problēmas

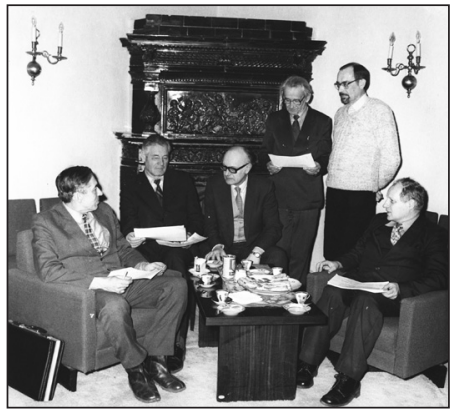

14. Baltijas Zinātṇu vēstures konferences rīcibas komitejas sēde Rīgā 1985. g. februārī Medicīnas vēstures muzejā. No kreisās: fiz. mat. zin. kand. L. Reizinšs, vēst. zin. kand. T. Vilciņš, doc. K. Ë. Arons, biol. zin. kand. J. Jākobsons, med. zin. kand. A. Vỉksna, akad. J. Stradiņ̌

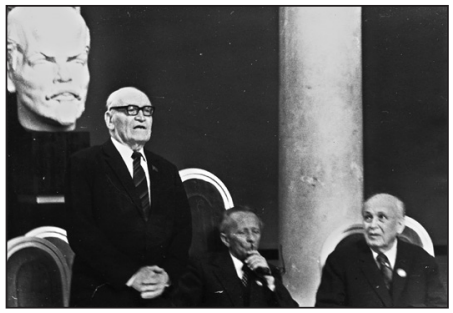

Vilnnas Universitātes jubilejai veltìtajā 12. Baltijas Zinātṇu vēstures konferencē 1979. g. Konferences dalībniekus uzrunā Latvijas Dabaszinātnu un tehnikas vēsturnieku apvienības priekšsēdētājs akad. P. Valeskalns. Pa labi Vilnnas Universitātes rektors akad. J. Kubiḷus, Lietuvas Dabaszinātñu un tehnikas vēsturnieku apvienỉbas priekšsēdētājs akad. P. Slavens 
arī PSRS nekrievu tautības zinātniekus, lai neveicinātu vietējo nacionālismu vai reǵionālo lokālpatriotismu.

Nostādnes manāmi mainijiās pēc Staḷina nāves G. Mal̦enkova un N̦. Hruščova valdīšanas gados. Notika zināma režīma liberalizācija, ko izmantoja savienoto republiku komunistiskā elite un zinātniskā inteliǵgence. Var runāt par "Hruščova atkusni" ("ottepelj"), kas Latvijā izpaudās kā nacionāli iekolorētais "Berklava atkusnis". Turklāt laika ziṇā tas sakrita ar zinātnes prestiža krasu pieaugumu toreizējā Padomju Savienībā, ar šīs lielvalsts panākumiem raķešbūvē un kosmosa tehnologijāas, kodolenerğijas jomā, ar tendencēm veidot zinātnietilpīgas izstrādes un ražošanas "kimizāciju". Notika arī decentralizācija zinātnē, no Maskavas un L̦eņingradas zinātne pārgāja arī uz savienotajām republikām. Padomju Latvijā, piemēram, tika atjaunots Rīgas Politehniskais institūts (1958), Zinātṇu akadēmijas sastāvā dibināts Organiskās sintēzes institūts (1957), legalizēts Medicīnas vēstures muzejs (1957), radās vairāki populārzinātniski žurnāli un biedrības, jauni, perspektīvi zinātnes virzieni.

Arī "lielajā" padomju zinātnē atjaunojās sakari ar kolẹgiem ārzemēs - PSRS zinātnieki sāka piedalīties starptautiskās organizācijās un kongresos. Tika reorientēti arī zinātṇu vēstures pētījumi PSRS - no šaubīgu "prioritāšu" meklējumiem uz ideju un tehnologiiju vēstures pētniecību pasaules mērogā, akcentējot arī vietējās īpatnības. 1956. gadā tika nodibināta Padomju Nacionālā Dabaszinātṇu un tehnikas vēsturnieku apvienība, ko uzn̄ēma par biedru IUHPS (Starptautiskajā Dabaszinātṇu vēstures un filozofijas savienībā, tā skaitījās ar UNESCO asociēta organizācija un tobrīd to vadīja slavenais fizikis Nobela prēmijas laureāts L. V. de Brojī) [3]. Padomju Nacionālā apvienība organizēja savas nodal̨as savienotajās republikās [4], arī Latvijā (1958), Lietuvā (1964) un Igaunijā (1967). Latvijā attiecīgo nodaḷu (sākumā - Latvijas nacionālo grupu), tagadējo Latvijas Zinātṇu vēstures asociāciju, tika nolemts organizēt ar 1958. g. 30. janvāra Latvijas PSR ZA Prezidija lēmumu [5]; lēmumu īstenoja 1958. g. 26. maijā, par jaunās organizācijas priekšsēdētāju ievēlot toreizējo LPSR ZA akadēmiķi sekretāru Pēteri Valeskalnu (1899-1987) [6], bet par atbildīgo sekretāru Jāni Stradiṇu, tolaik Organiskās sintēzes institūta vecākā zinātniskā līdzstrādnieka vietas izpildītāju $[7,8]$.

Tajā pašā laikā latviešu mediḳis un medicinas vēsturnieks profesors Pauls Stradinsš (1896-1958) intensīvi veidoja savu Medicinas vēstures muzeju Republikas klīniskās slimnīcas telpās [9]. Šā muzeja nodošanu valstij, dibinot juridisku valsts iestādi, viņam izdevās ìstenot 1957. g. septembrī. Mūža pēdējais cēliens P. Stradiņam bija īpaši intensīvs. Viņš organizēja ne vien vēža k̦īmijterapiju, sirds operācijas, torakālo ķirurǵiju un medicīnas vēstures muzeju, bet arī sakomplektēja regulāri iznākošos medicinas vēstures rakstu krājumus "Iz istorii mediciny" (tā pirmais sējums iznāca 1957. gadā). Jau kopš 1952. gada P. Stradiņš loloja ieceri sasaukt Baltijas Medicīnas vēsturnieku konferenci Rīgā, sākotnēji - sakarā ar Rīgas 1. pilsētas slimnīcas 150 gadu jubileju (vecākā slimnīca mūsdienu izpratnē Baltijā, dibināta 1803. gadā), vēlāk - sakarā ar Medicīnas vēstures muzeja atklā- 
šanu [10]. Viņš bija guvis šai ierosmei atbalstu gan no Maskavas, L̦eningradas un Ukrainas, gan no abām pārējām Baltijas republikām. Maskavas "ārstu indētāju" lieta (1953. gada sākumā) un J. Stạlina nāve aizkavēja šo nodomu īstenošanu uz vairākiem gadiem, līdz 1956. gada nogalē P. Stradiṇu piemeklēja insults.

Atkopies no insulta un legalizējis Medicīnas vēstures muzeju, 1958. gada sākumā P. Stradiņš atgriezās pie konferences idejas un uzaicināja pie sevis mājās Lietuvas un Igaunijas kolēǵus pārrunāt konferences sasaukšanu. Baltijas valstu vienotības ideja P. Stradiņam bija tuva jau kopš pirmskara laika - 1938. gadā vin̄š aktīvi piedalījās t. s. Baltijas nedēḷas organizēšanā Rīgā, veidoja plašus sakarus ar Lietuvas, Igaunijas un Somijas mediķiem. Arī pēc kara, jau 1945. gadā, P. Stradinš̌ bija organizējis Rīgā un Ķemeros Baltijas republiku medicinas zinātnisko padomju pirmo sesiju. Tāpat viņš bija referējis Igaunijas PSR ZA 1. zinātniskajā sesijā 1947. gadā par Baltiju kā vienotājposmu starp Krievijas un Rietumu medicīnu [11].

Koordinatīvajā apspriedē P. Stradiņa mājās kabinetā, Ventspils ielā 19, kur no Igaunijas (Tartu) piedalījās biokīmijas profesors Eduards Martinsons, bet no Lietuvas - parazitologs Stasis Bizjulevičs, tika nolemts Rīgā noturamo konferenci veltìt ne vien medicīnas, bet arī dabaszinātṇu vēsturei. Galvenais konferences uzdevums bija Starprepublikāniskas Baltijas dabaszinātṇu vēstures problēmu komisijas dibināšana, kas koordinētu pētijumus šajā virzienā un pulcinātu pētniekus interesentus. Apspriedē vēl piedalijās Latvijas PSR Medicīnas vēsturnieku biedrības toreizējais sekretārs medicinas apakšpulkvedis Konstantins Vasiḷjevs un arī es, tolaik jauns zinātnieks, kas vienlaikus ar darbu Organiskās sintēzes institūtā biju arī Medicinas vēstures muzeja darbinieks un faktiski veicu sava slimojošā tēva privātsekretāra pienākumus. Sākotnēji bija iecerēts konferenci saistīt ar Medicīnas vēstures muzeja atklāšanu jaunajās telpās 1958. gada rudenī, taču P. Stradiṇš, kā likās, jau paredzēja, ka muzeja veidošanās var ieilgt, nenotiekot tik strauji, tādēḷ viņš steidzināja konferences sarīkošanu, itin kā paredzēdams, ka rudeni pats vairs nepieredzēs. Konferenci nolēma rīkot maija beigās-jūnija sākumā, un visi organizatoriskie darbi - referātu komplektēšana, ielūgumu izsūtišsana - bija jāuzṇemas man.

Lai gūtu akceptu rīkot konferenci, Latvijas PSR ZA vārdā 1958. g. 24. aprīlī uzrakstijāam vēstuli akadēmiķim sekretāram P. Valeskalnam [12], pēc tam kad bijām sañēmuši atbalstu no vairākiem prominentiem Maskavas zinātṇu vēsturniekiem (prof. B. Petrova, S. Soboḷa un L. Bḷahera un paša PSRS ZA Dabaszinātṇu un tehnikas vēstures institūta direktora prof. N. Figurovska). N. Figurovskis ne vien atbalstija priekšlikumu par Baltijas Dabaszinātņu un medicīnas vēstures problēmu komisijas dibināšanu, bet pat izteica domu, ka "tai varētu tikt pieškirtas tiesības un iespējas piedalīties starptautiskās organizācijās par zinātṇu vēsturi un farmācijas un medicīnas vēsturi" (N. Figurovska vēstule P. Stradiṇam 1958. gada 8. aprīīi) [10]. Arī P. Valeskalns principā atbalstijja konferences ieceri, gan nevirzot šo jautājumu ne uz kādu oficiālu saskaṇošanu vai apstiprināšanu Latvijas PSR Zinātṇu 
akadēmijas prezidijā vai Latvijas Kompartijas CK, kas tolaik skaitijās normāla, pat nepieciešama procedūra. Un šajā ziṇā viṇam, protams, bija taisnība, jo birokrātiskās procedūras visu būtu ievilcinājušas.

Tieši šajā laikā Latvijas PSR Zinātṇu akadēmija, tās prezidijs un nodaḷas pārcēlās uz ZA Augstceltni ("Kolhoznieku namu"). Toreizējā ZA lielā konferenču zāle Latvijas PSR ZA Fundamentālās bibliotēkas (dib. 1524) ēkā ("Muses namā") daḷēji bija jau izārdīta, lai tur iekārtotu galveno lasītavu. Trijatā ar tēvu un bibliotēkas komandantu sastūmām jau iegādātos krēslus un galdiṇus konferences noturēšanai. Fundamentālās bibliotēkas darbiniece M. Taube draudzīgā kārtā bibliotēkas vestibilā iekārtoja seno Rīgas zinātnisko grāmatu unikālu izstādi no saviem "retumiem", lai uzskatāmi rādìtu Baltijas zinātnes tradīcijas 17.-20. gs.

Par šo grāmatu izstādi saglabājies toreizējās Fundamentālās bibliotēkas Retumu sektora vadītājas Dr. Metas Taubes pieraksts viṇas dienasgrāmatā, kuru Baltijas zinātnes vēstures grāmatu un dokumentu izstādē pēc 50 gadiem rādīja bibliotekāre Arta Poriete. Lūk, "Taubītes" atmiņas:

"6. VI [1958] sarīkoju izstādi uz prof. Stradiṇa (ḳirurga) vēlēšanos sakarā ar konferenci, kas bija sarīkota kopīgi ar kaimiņu republikām medicīnas-dabaszinātṇu vēsturē. Nonāca uz izstādi vecais profesors Stradiṇš ar dēlu Jāni, meitu (mākslinieci), kā arī ar konferences dalībniekiem. Apskatīja rokrakstus, kā arī vecās iespiestās grāmatas (eksponātu ap 104), arī prof. Stranda materiālus (kas ar sevišķu mīlestību pētīis zirnekḷus). Prof. Stradiņš, neskatoties uz savu slimību (asinsizplūdumu, ko viņš pirms pāris gadiem pārcieta), tomēr ḷoti rosīgs un jau steidzās prom no izstādes uz slimnīcu. Operācijas pats viṇš gan vairs neizdarot, bet asistējot nopietnākās operācijās. Viņš teica: "Jūs mani atvainosiet, turpiniet vien skatîties izstādi, bet man jāsteidzas uz slimnīcu!". Tā ir autentiska laikmeta liecība.

Konference notika tagadējā Vāgnera zālē 1958. g. 6. jūnijā ar divām sēdēm un apm. 60 dalībniekiem $[13,14]$. Nākamajā dienā referāti vairs netika lasīti, taču notika Medicīnas vēstures muzeja apskate Valsts klīniskās slimnīcas barakā un pieņemšana P. Stradinna mājās, turpat pretī, Ventspils ielā 19. Vairāki programmā paredzētie referenti neatbrauca (Tartu Universitātes rektors prof. F. Klements, fiziolog̣ijas profesors V. Lašs no Kauņas. Nebija ieradies arī uzaicinātais medicīnas vēsturnieks $B$. Petrovs no Maskavas un pat viens no konferences iniciatoriem - prof. E. Martinsons no Tartu. Taču referentu skaitā bija daudzi prominenti zinātnieki, kā, piemēram, prof. P. Slavens (Lietuvas PSR ZA Zinātṇu vēstures komisijas priekšsēdētājs), prof. V. Girdzijausks un S. Bizjulevičs no Lietuvas, V. Kalnins un K. Villako no Igaunijas, pavisam kādi 7-12 cilvēki no citām republikām, bet no Latvijas - Zinātṇu akadēmijas locekḷi A. Kalniņšs, S. Hillers, P. Gērke, J. Mihailovs, P. Valeskalns, grāmatnieks K. Egle, zinātnieki E. Karpovics, F. Grigorašs, V. Utkins, zinātṇu vēsturnieki G. Nikolajeva-Seredinska, J. Jākobsons, Ā. Karnups, A. Laksbergs, S. Magilı̧ıickis, K. Vasiḷjjevs, I. Rabinovičs. Tika nolasīti 9 referāti, kuru starpā centrālais 
bija P. Stradiṇa un J. Stradiņa kopreferāts par Baltijas zinātṇu vēstures pētǐšanas pamatproblēmām [15]. Tā pamattēzes tika iekḷautas apspriedes rezolūcijā, un šîs akceptētās tēzes bija šādas:

1. Baltijas republiku zinātṇu centri no laika gala ir bijuši savā starpā vienoti, un tiem ir bagātas tradīcijas. Tērbatas (Tartu) Universitātē, Viḷnas Universitātē, Rìgas Politehniskajā institūtā un Latvijas Universitātē, tāpat Kauṇā un Jelgavā 17.-20. gs. veidojušās oriǵinālas zinātnieku skolas, aktīvas bijušas dabaszinātņu, kīmiḳu, farmaceitu, mediķu biedrības, Baltijā darbojušies ievērojami zinātnieki. Baltijas zinātṇu centri ir bijuši cieši saistìti ar Krievijas un kaimiņzemju (Polija, Vācija, Skandināvijas valstis) zinātniekiem.

2. Viss vērtīgais un progresīvais neatkarīgi no zinātnieka tautības pieder Baltijas nāciju kultūras mantojumam, tas rūpīgi jāpētī, jāizvērtē un jāpopularizē gan Baltijas republiku sabiedrībā, gan Vissavienības un pasaules zinātnieku auditorijā.

3. Lìdz šim pētijjumi par zinātṇu vēsturi veikti epizodiski, pēc atsevišķu entuziastu ierosmes, bez kopēja pārdomāta plāna. Jārada koordinācijas centrs - Baltijas Medicīnas un dabaszinātṇu vēstures pētniecības starprepublikāniska komisija, kas regulāri pulcētos uz sanāksmēm (konferencēm) Rīgā, Viḷnā, Tartu, Kauṇā.

4. İpaša uzmanība pievēršama Baltijas zinātṇu centru saistỉbai ar krievu zinātni, parādot to savdabīgo vietu Krievijas un pasaules zinātnē.

5. Jāatzīmē izcilo zinātnieku piemiņas reizes, jāizdod to komentētas darbu izlases, jāsaglabā zinātnieku, zinātnisko iestāžu un biedrību arhīvi, jācenšas pārvest atpakal uz Rìgu no Ivanovas atjaunojamā Rīgas Politehniskā institūta vērtīgo bibliotēku. Ne mazāk svarīgi ir saglabāt un sistematizēt arī pašreiz funkcionējošo zinātnisko iestāžu, augstskolu arhīvus, veicināt zinātnieku un zinātnisko iestāžu bibliogrāfiju izdošanu.

6. Jāpopularizē aizgājušo gadsimtu zinātnieku veikums presē, radio, muzeju ekspozīcijās, jāaktivizē pētījumi tehnisko un eksakto zinātṇu vēstures jomā, jāturpina izdot rakstu krājumu "Iz istorii mediciny", Medicīnas vēstures muzejā jāizveido Baltijas Medicīnas vēstures nodaļa ar materiāliem arī no Lietuvas un Igaunijas.

7. Zinātṇu vēstures pētniecībai jāpiesaista arī humanitāro zinātṇu pētnieki (etnogrāfi, arheologi, folkloristi, literatūrzinātnieki, bibliogrāfi, arhīvu darbinieki u. c.).

Šodien visi citētie secinājumi šķiet pašsaprotami, pat triviāli, taču tolaik tie šķita ideolog̣iski "aizdomīgi" diskutabli, ja ne tūdal ideolog̣iski noraidāmi. Īpaši svarīgi bija mainīt attieksmi pret Baltijas vāciešu zinātniekiem, pret kuriem ne tikai oficiālajās varas struktūrās, bet arī plašākā sabiedrībā attieksme bija noraidoša. Viṇus vai nu "pārtaisīja" par krieviem (K. M. Bēru), vai noklusēja, vai arī citēja vienīgi kritiskā aspektā (kā V. Ostvaldu). Šo zinātnieku pakāpeniska atzīšana pamazām l̦āva objektīvi izklāstīt Tartu Universitātes un arī Rīgas Politehniskā institūta vēsturi, vispār ķerties pie Baltijas zinātṇu vēstures, jo lìdz 20. gs. sākumam 


\section{J. Stradiň̌}

Baltijas vācieši (un savukārt - poḷi Viḷņas Universitātē) būtībā bija galvenie, ja ne vienīgie, kas darbojās zinātnē.

Bet galvenais - šĩ un nākamās konferences l̦āva apzināties reǵionālo identitāti, pamazām saliedēja baltiešus vismaz zinātnes un augstskolu pagātnes izpētē, radija iekšēju rezistenci pret padomju unifikāciju un lielkrievu šovinismu. Ar saturu tika piepildīta prof. D. A. Lēbera vēlākā tēze: "Regional Identity under the Soviet Rule". Veidojās lokālpatriotisms šā vārda labā nozīmē. Protams, konferenču dalībnieki bija ḷoti dažādi, - to skaitā bija arī daudzi karojošā komunisma piekritēji un lielkrievu šovinisti, taču vini "nenoteica toni".

Pauls Stradiņš nomira divus mēnešus pēc pirmās konferences - 1958. gada 14. augustā, bet viṇa iedibinātā ierosme nepagaisa - jau 1959. gadā notika divas nākamās konferences (janvārī Tartu un decembrī Viḷnā-Kauņā), kuras organizēja attiecīgi prof. E. Martinsons un prof. P. Slavens. Kopš 3. konferences sāka izdot konferenču tēžu krājumus. Konferenču dalïbnieku skaits pieauga. Dažas konferences bija veltītas galveno augstskolu jubilejām (4. konference Rīgā 1962. gadā - RPI 100 gadiem, kam bija ḷoti liela nozīme atjaunotā RPI pēctecības atzǐšanai ar "veco" RPI, 11. konference Tartu, 1977. gadā oktobrī - Tartu Universitātes atjaunošanas 175 gadiem, 12. konference Viḷnā - 1979. gadā Viḷnas Universitātes 400 gadiem, 13. konference Tartu 1982. gada novembrī - Tartu Universitātes pirmdibināšanas 350 gadiem, 15. konference Rīgā 1987. gada septembrī - RPI 125 gadiem). Citām konferencēm bija tematisks raksturs, piemēram, 7. konference Rīgā 1968. gadā bija veltìta Baltijas vidutājlomai zinātnisko sakaru veidošanā starp Krieviju un Rietumiem zinātnē 17.-20. gs., 10. konference Rīgā 1975. gada aprîlī - Pēterburgas ZA ietekmei Baltijā un arī Academia Petrina vēsturei (izbraukuma sesija Jelgavā sakarā ar augstskolas dibināšanas 200 gadiem) [16-18].

Viena no nozīmīgākajām konferencēm, kurā bija 700 klausītāju (190 reǵistrētu dalībnieku!), notika Jūrmalā un Rīgā 1985. gada februārī (14. konference), un to rīkoja Organiskās sintēzes institūts. Tās tematiku iezīmēja trīs problēmu loki: 1) zinātnisko kolektīvu un zinātnisko skolu tapšana Baltijā; 2) agrīno zinātnisko priekšstatu veidošanās, pēc folkloras un arheologijas datiem (Krišjāṇa Barona 150 gadu jubileja); 3) zinātnes un tehnikas pieminekḷi.

Laikam skaitliski tā ir bijusi visplašākā konference, ar rezonansi sabiedrībā tieši pirms Gorbačova nākšanas pie varas. Neticami, ka tik daudz dalïbnieku, un šodien tikpat neticami, ka par zinātnes un tehnikas pieminekḷiem sprieda planetārijā ("Zinību namā"), kas tolaik bija iekārtots tagad atjaunotajā pareizticīgo Kristus piedzimšanas katedrālē!

Baltijas Zinātṇu vēstures konferenču rīkošanai - gan samērā atturīgi - atbalstu sniedza padomju Dabaszinātṇu un tehnikas vēsturnieku nacionālā apvienība, tās vadošie pārstāvji referēja konferenču plenārsēēēs. Arī PSRS Medicīnas vēsturnieku biedrības (vēlāk - PSRS Sociālhigiēnistu, veselības aizsardzības darbinieku un medicīnas vēsturnieku biedrības) pārstāvji nereti piedalījās šajās konferencēs - dažkārt ar "direktīvu uzstādījumu" referātiem, kā, piemēram, prof. B. Petrovs. Tomēr 
šì biedrība bija manāmi "stagnātiskāka" nekā Dabaszinātṇu un tehnikas vēsturnieku nacionālā apvienība, kuras zinātniskais līmenis bija krietni vien augstāks.

Taču lielos vilcienos Baltijas Zinātṇu vēstures konferences visu to sasaukšanas laikā tika organizētas autonomi, neatkarīgi no Maskavas padomdevējiem. Varbūt varētu atzīmēt Latvijas Dabaszinātṇu vēsturnieku apvienības priekšsēdētāja P. Valeskalna īpašos kontaktus ar Padomju Nacionālās Dabaszinātṇu un tehnikas apvienības vadītājiem un PSRS ZA Dabaszinātṇu un tehnikas vēstures institūta ilggadējo direktoru akadēmiḳi Bonifāciju Kedrovu (1903-1985), - viṇi abi 20. gados bija darbojušies VČK orgānos Maskavā. Tas savā ziņā garantēja Baltijas pasākumiem B. Kedrova ìpašu labvēlību (viṇš pats piedalijāas Baltijas Zinātṇu vēstures konferencēs 1962., 1964., 1965., 1970., 1975. un 1977. gadā). Brežṇeva laikā Kedrovs ieņēma "antistalıinisku" nostāju un palīdzēja sekmēt daža laba Stalıina represētā zinātnieka (piemēram, R. Üdra, J. Stieṇa) vārda reabilitēšanu.

1987.-1991. gada, Atmodas gados, konferenču rīkošanā bija visilgākais pārtraukums, taču tāds nebija Baltijas zinātṇu vēstures asociāciju aktivitātēs.

Vispirms pēc Igaunijas zinātṇu vēsturnieku (K. Sïlivasks, K. Martinsons) ierosmes tika izveidota Baltijas Zinātnes vēstures koordinācijas padome, kuras dibināšanu vispirms apstiprināja Latvijas PSR ZA Prezidijs savā 1988. gada 10. februāra sēdē (dibināšanu atbalstīja ZA prezidents B. Purinšs un viceprezidents A. Drīzulis, kamēr krasi ar naidu oponēja prezidija loceklis bij. ZA prezidents A. Mālmeistars). Pēc tam to apstiprināja Igaunijas PSR ZA Prezidijs un principā atbalstīja arī Lietuvas PSR ZA vadiba.

1988. gada 19. maijā Maskavas Dabaszinātņu un tehnikas vēsturnieku nacionālās apvienības vadītāju plēnumā piedalījās "baltieši" J. Krikštopaitis, H. un K. Martinsoni P. Mīriseps vec., T. Vilciņš un J. Stradiņš. Visu "baltiešu" vārdā plašu runu plēnumā sacīja J. Stradiņš, paziņojot arī par koordinatīvās padomes dibināšanu un neatkarīgu darbību, reizē arī turpinot zinātṇu vēsturnieku apvienību visās trijās republikās un uzturot kontaktus ar Padomju Nacionālo apvienību, pieņemot tās konsultācijas zinātṇu vēstures profesionālajos jautājumos. Plēnumu vadīja toreizējais PSRS ZA Dabaszinātņu un tehnikas vēstures institūta jaunais direktors, fizikikis PSRS ZA korespondētājloceklis Nikolajs Ustinovs (bij. PSRS aizsardzības ministra $\mathrm{D}$. Ustinova dēls). Viňš atbalstīja baltiešu iniciatīvas M. Gorbačova pārbūves ideju gaisotnē un pat nožēloja, ka neprotot par to pateikt paldies, jo latviski protot tikai vienu vārdu "lūdzu".

Tas bija pirmais augstākstāvošas zinātniskās instances lēmums par Baltijas zinātṇu vēstures pētijumu nodibināšanu, jo 1958. gada konference dibināja Baltijas Dabaszinātṇu un Medicīnas vēstures starprepublikānisko komisiju tikai neformālā kārtā; tā îsti netika sankcionēta un ap 1964. gadu faktiski "pagaisa", nododot savas funkcijas triju republiku Dabaszinātn̦u vēsturnieku apvienībām. Kad trīs Baltijas republikas 1990. gadā bija deklarējušas neatkarības atjaunošanu, 1990. gada 29. oktobrī P. Stradiņa Medicinnas vēstures muzejā pulcējās visu triju valstu zinātṇu vēstures apvienību aktīvisti (K. Sïlivasks, J. A. Krikštopaitis, J. Stra- 


\section{J. Stradinš}

diņš, K. Ė. Arons u. c.) un nodibināja apvienotu Baltijas valstu Zinātņu vēstures un filozofijas asociāciju $[19,20]$. Šis akts tātad notika pēc triju valstu neatkarības atjaunošanas deklarēšanas, bet pirms 1991. gada 21. augusta. Jaundibinātās asociācijas līdzprezidenti bija republiku attiecīgo apvienību vadītāji - prof. J. Krikštopaitis Lietuvā, prof. J. Stradiņš Latvijā, prof. K. Sīlivasks Igaunijā (līdz 2006. gadam, pēc tam prof. J. Āvikso, tagadējais Igaunijas Republikas aizsardzības ministrs). Kop̌̌ 2006. gada prezidenta funkcijas pirmais veica J. Stradiņš Rīgā.

Jau 1991. gada 13. janvārī asociācijas prezidents sniedza Latvijas radio paziṇojumu pasaulei (latviešu, ang̣̣u un krievu valodā), atbalstot Lietuvas neatkarỉbu un nosodot padomju karaspēka brutālo vardarbību Viḷnā pie televīzijas ēkas (teksts - 2. pielikumā 256. lpp.). Tajā pašā gadā sabruka PSRS, un visas trīs Baltijas valstis augustā galīgi atguva neatkarỉbu. 1991. gada 4.-6. oktobrī 16. konference notika Viḷnā - kā pati pirmā neatkarību atguvušo Baltijas valstu kopēja zinātniska konference vispār. Šìs konferences kopsaucējs bija: "Zinātnes vēsturiskā pieredze Baltijas republiku valstiskuma atjaunošanā". Tātad 15 Baltijas zinātṇu vēstures konferences bija notikušas 30 gadu laikā pirms Baltijas valstu neatkarības atjaunošanas (1958-1987), bet 8 sarīkoja jau neatkarīgās Baltijas valstis 17 gados (1991-2008). 1993. gadā Saragosas kongresā Baltijas valstu Zinātṇu vēstures un filozofijas apvienība kā vienots vesels tika uzṇemta Starptautiskajā Zinātṇu vēstures un filozofijas savienībā. Jāatzīmē, ka Baltijas zinātņu vēsturnieki bija jau kā PSRS pārstāvji visai aktīvi piedalījušies vairākos iepriekšējos zinātṇu vēsturnieku kongresos - Krakovā (1965), Maskavā (1971), Tokijā un Kioto (1974), Bukarestē (1980), iesūtỉjuši savus referātus arī Edinburgas (1977) un Bērklijas (1984) kongresā. Viṇiem bija labi kontakti starptautiskajās zinātṇu vēsturnieku organizācijās, kuri neatkarības gados - paradoksālā kārtā - gājuši mazumā.

PSRS politikas ietvaros šìs konferences bija būtisks triju republiku sadarbības veids, jo oficiāli kontakti tikai triju Baltijas republiku starpā netika veicināti. Maskavas, L,eņingradas u. c. pilsētu prominento zinātṇu vēsturnieku klātiene nostiprināja konferenču reputāciju, l̦āva atklāt jaunus, Baltijā vēl nezināmus faktus. Zinātniskais līmenis bija pietiekami augsts, dalībnieki centās pārvarēt provinciālismu. Dabaszinātṇu un eksakto zinātņu specifikas dẹḷ komunistiskā režīma laikā par strīdīgām problēmām varēja runāt objektīiāk nekā vispārējā vēsturē, diskutēt par to, kas tolaik skaitîjās aizliegts vai ideologiski ḳecerīgs.

Daudzos gadījumos zinātṇu vēsturē izdibinātais ḷâva jaunas atziṇas iekḷaut arī dažos vispārvēsturiskos pētījumos, piemēram, par kultūras vēsturi, universitāšu, zinātnisko biedrību vēsturi. Neērtie jautājumi skāra Baltijas vāciešu lomu Krievijas kultūras vēsturē, Stalıina režīma represēto zinātnieku likteni (piemēram, R. Ūdri, J. Auškāpu u. c.), seno baltu cilšu dzìvesziṇu, turklāt izmanīgā veidā tika rādīti arī neatkarīgo Baltijas valstu zinātnieku sasniegumi pirmskara posmā. Tas l̦āva zinātnes vēsturniekiem pārdzīvot sovjetizācijas kritiskos gadus, saglabājot eiropeisku mentalitāti. Zinātṇu vēstures konferences tuvināja ne tikai dažādu dabaszinātṇu nozaru pētniekus, bet arī dabaszinātniekus ar humanitāro zinātṇu pārstāvjiem, 
veicinot starpdisciplināras pieejas, dabaszinātṇu humanitarizāciju, "divu kultūru" tuvināšanos Č. Snova izpratnē. Varēja iztirzāt netradicionālo medicīnu, paleoastronomiju, zinātnes elementus folklorā.

No neatkarības gados notikušajām konferencēm minama arī 17. konference Tartu (1993. gada oktobrī) ar tematiku "Zinātne Baltijā starp Rietumiem un Austrumiem", kas notika līdz ar VFR zinātṇu vēsturnieku rīkotu simpoziju, un īpaši 18. konference Rīgā (1996. gada janvārī) ar tematiku "Zinātnes funkcionēšana lielvalstī un mazā valstī: Baltijas pieredze" un Paula Stradiña 100. gadadienai veltìts simpozijs "Medicinnas vēsturnieki - profesionāḷi un amatieri" ar plašu starptautisku līdzdalību, kas atkal bija viena no plašākajām.

21. Baltijas Zinātṇu vēstures konferences laikā (Rīgā 2003. gada oktobrī) tika atklāta slavenā ḳīmiķ̣a Paula Valdena piemiṇas zīme pie bijušās RPI Ķīmijas nodal̦as ēkas (tēlnieks A. Vārpa), kā arī godināta Nobela prēmijas laureāta Vilhelma Ostvalda piemiña sakarā ar viṇa 150. dzimšanas dienu pie nesen viṇam veltītā pieminekḷa Krišjāṇa Barona ielā (tēlnieks A. Vārpa) un LU Mazajā aulā (bij. RP aktu zālē, kur bija lekcijas lasījis arī pats V. Ostvalds).

Visu šo konferenču organizētāja formāli ir Baltijas valstu Zinātņu vēstures un filozofijas asociācija; šo konferenču noturēšana būtībā ir asociācijas galvenais, ja ne vienīgais uzdevums.

Lìdz Baltijas valstu neatkarības atgūšanai konferenču darba valoda bija krievu valoda; tiesa, konferencēs bija atsevišḳi l̦ loti nedaudzi ārzemju viesi (no Polijas, Vācijas, Bulgārijas, ASV), kas nereti referēja arī angḷu vai vācu valodā. Lektoru vidū ir bijuši tādi prominenti viesi kā, piemēram, Maskavas profesori un Starptautiskās Zinātṇu vēstures akadēmijas locekḷi V. Naḷimovs, S. Mikuḷinskis, A. Juškevičšs, B. Kedrovs, N. Figurovskis, A. Grigorjans, N. Rodnijs, V. Kuzņecovs, J. Solovjovs, M. Jaroševskis, A. Šamins, G. Bikovs, tāpat Ukrainas, Moldovas, Baltkrievijas, Gruzijas akadēmiju locekḷi un citi zinātnieki (M. Eljaševičs, A. Veiniks, A. Bogoḷubovs, J. L̦alịkovs, J. Fialkovs, V. Parkadze u. c.), latviešu cilmes geologs un mineralogs A. Dzens-Ľitvinskis.

No pastāvīgiem konferenču dalïbniekiem un referentiem pieminami prof. F. Klements, prof. E. Martinsons, prof. K. Silivasks, prof. U. Palms, prof. İ. Lumiste, prof. V. Pasts, doc. E. Vareps, Dr. H. Martinsone, Dr. K. Martinsons, doc. P. Mïrseps vecākais, doc. H. Ēlsalu, doc. T. Ilometss, doc. V. Kalnins, Dr. E. Tamiksārs, Dr. H. Tanklers, prof. R. Vihalems, L. Kongo, H. Gustavsons no Igaunijas; prof. P. Slavens, prof. J. A. Krikštopaitis, prof. L. Klimka, prof. S. Bizjulevičs, prof. V. Girdzijausks, prof. A. Tila, doc. V. Sjūdiks, Dr. V. Kutorga, prof. K. Makarjūns, E. Gečkausks, P. Vitkevičs u. c. no Lietuvas; prof. P. Valeskalns, prof. P. Gērke, prof. J. Stradiņš, prof. I. Knēts, Dr. T. Vilcinsš, doc. J. Klētnieks, doc. A. Anteins, Dr. I. Grosvalds, doc. S. Timšāns, Dr. J. Jākobsons, doc. K. Arons, prof. A. Vỉksna, Dr. M. Pozemkovska, Dr. B. Mauriņa, Dr. A. Zigmunde, H. Hanzena, Ā. Karnups, A. Dirbe, H. Guḷevskis, U. Alksnis, E. Zalsters, I. Rabinovičs, K. Vasiljjevs, prof. J. Salaks, doc. J. Klētnieks, prof. A. Krūze, I. Kestere u. c. no Latvijas. 
Vairākās konferencēs piedalijušies ne vien vēsturnieki, bet arī Baltijas valstu zinātnieki - nacionālo ZA vadītāji un universitāšu rektori kā, piemēram, J. Matulis, J. Kubilı,s, B. Jodka, Z. Rudziks, T. Millers, J. Ekmanis, K. Rebane, J. Engelbrehts, P. Tūlviste, M. Veidermā, J. Āvikso, A. Kops, P. Zariņšs, O. Ozols, J. Zaķis, I. Lācis, un prominenti Baltijas valstu zinātnieki - ZA locekḷi L. Liepiņa, G. Vanags, Arv. Kalniņ̌̌s, A. Ieviņš̌, S. Hillers, M. Šimanska, E. Lukevics, A. Alksnis, R. Kukaine, K. Karulis, M. Beķers, G. Duburs, I. Lazovskis, H. Strods, R. Kondratovičs, I. Rašals, U. Sedmalis, J. Anšelevičs, M. Kḷaviņš, A. Raukass, A. Ārna, K. Orviku, H. İglane, H. Keress, Č. Kudaba, J. Jurginis, P. Vaškelis, A. Buračs, A. Tila u. c., tāpat arī augstākās izglîtības celmlauži Igaunijā un Lietuvā - V. Ernitss un Z. Žemaitis. Konferencēs piedalījušies ievērojami Eiropas valstu zinātṇu vēsturnieki ārpus Baltijas, piemēram, K. Debrī, A. Leikola, U. Dini, R. Ajī (Hauy), D. fon Engelharts. Par Baltijas Zinātṇu vēstures asociācijas darbību publicēti informatīvi pārskati starptautiskos zinātṇu vēstures izdevumos [21, 22].

Pēc neatkarības atgūšanas aktuāls kḷuvis jautājums par konferenču darba valodu (lingua franca), jo krievu valodu vairās lietot, bet angḷu vai vācu valodu daudzi konferenču dalībnieki (īpaši gados vecāki cilvēki) ne visi labi saprot. Tematika kḷuvusi lokālāka, provinciālāka, radusies pašpietiekamība. Par tradīciju kḷūst LU un RTU gadskārtējo konferenču ietvaros zinātņu vēstures un muzeoloǵijas sekciju rỉkošana. Tas ir ḷoti labi, tomēr tam nevajadzētu būt vienīgajiem zinātṇu vēsturnieku forumiem Latvijā.

Šogad atskatījāmies arī uz Latvijas Zinātṇu vēstures asociācijas 50 gadu pastāvēšanu - tās vēsturi [1]. Mūsu devums, kā arī nedaudzu kaimiṇu devums parādīts Latvijas Akadēmiskajā bibliotēkā organizētajā grāmatu, izdevumu, tēžu krājumu, fotogrāfiju izstādē. Bez tam šajās dienās (13. oktobrī) tiek atklātas piemiņas zīmes vienīgajam Nobela prēmijas laureātam no Baltijas - rīdziniekam Vilhelmam Ostvaldam un viṇa Rīgā apbedītajiem vecākiem, kā arī izcilajam ķīmiķim analītiķim Edvardam Iegrīvem. Tās atrodas Rīgas Lielajos kapos, t. i., slēgtajos kapos, papildinot ar attiecīgiem uzrakstiem tur jau esošos kapu pieminekḷus. Pirms tam jau atklāts atjaunotais kapu piemineklis ķīmijas profesoram V. M. Fišeram un skaista piemiņas zīme raķešbūves aizsācējam F. Canderam (tēlnieks I. Ranka): visu šo pieminekḷu tapšanu sponsorējis Itera Latvija prezidents LZA goda mecenāts Juris Savickis.

Sakarā ar konferenci Latvijas Zinātṇu akadēmijas Senāts, kas aprūpē Latvijas Zinātṇu vēstures asociāciju, 2008. gada 16. septembrī ir apstiprinājis Asociācijas goda biedru nosaukumu vairākiem kolēǵiem. To skaitā goda biedra nosaukums pieškirirts:

akad. Ivaram Knētam - par devumu vecākās Latvijas augstskolas RTU attīstìbā un vēstures izpētē;

prof. Libertam Klimkam (Lietuva) - par devumu Baltijas zinātṇu vēstures izpētē; 
Dr. Haino Tankleram (Igaunija) - par Tērbatas Universitātes un Latvijas zinātnisko sakaru izpēti;

LZA ārzemju loceklim Jurim Upatniekam (ASV/Latvija) - par devumu hologrāfijas izgudrošanā un latviešu zinātnieku prestiža celšanu pasaulē;

Grētelei Brauerei (Vācija) - par nopelniem sava vectēva Vilhelma Ostvalda mantojuma izpētē un V. Ostvalda muzeja "Landhaus Energie" saglabāšanā;

emeritētam profesoram Jānim Lielmežam (Kanāda, Vankūverā) - par nopelniem Latvijas zinātṇu vēstures izpētē.

Citi līdzšinējie LZVA goda biedri uzrādīti konferences materiālu krājumā Nova Miscellanea Historiae Scientiarum Baltica [21], bet pilnīgs saraksts sniegts 3. pielikumā 257. lpp.

23. Starptautiskā Baltijas zinātṇu vēstures konference zināmā mērā ir ārkārtas. Tā ir zinātnes vēsturnieku kopības jubilejas, Baltijas vienotības izpausmes konference un kā tāda arī viena no skaitliski nelielākajām, salīdzinot ar iepriekšèjām. Zināmā mērā tas saistīts ar paaudžu maiṇu, vismaz Latvijas asociācijas biedru skaits ir sarucis, esam kḷuvuši vecāki (par LZVA darbību aizvadītajos gados sk. [21-31]). Arī zinātnes prestižs sabiedrībā ir sarucis. Līdz ar to mazinājusies arī interese par zinātnes vēsturi, ìpaši par eksakto un dabaszinātṇu vēsturi. Turklāt jaunākā zinātnieku paaudze ir pragmātiskāka, vairāk nodarbināta ar aktuālām pētniecības problēmām, mazāk - ar jēgas un vēstures izziņas meklējumiem. Tomēr, kaut lēni, arī zinātnes vēsturnieku paaudze atjauninās, taču tas vairāk notiek muzeju, bibliotēku, nevis institūtu un universitāšu darbinieku aprindās. Pieaug interese par humanitāro zinātṇu vēsturi, par zinātni kā kultūras mantojumu, arī par industriālo mantojumu. Vairāk ieslīgstam arī vietējās detaḷās, atomizējamies, dezintegrējamies. Problēma par Baltijas vidutājas lomu starp Krieviju un Rietumiem kḷuvusi mazāk aktuāla, tomēr varbūt varam izpētìt un sarakstīt Baltijas zinātnisko centru kopēju vēsturi kā Eiropas zinātnieku sabiedrības sastāvdaḷu, tās fragmentu.

Mūsdienu situācija liek pārdomāt nākotnes stratēégiju, varbūt mainìt akcentus. Vai zinātṇu vēsture nebūtu saistāma arī ar ideju vēsturi, kā tas notiek Ziemel̦valstīs? Vai zinātnes vēsture vairāk nebūtu saistāma ar mūsu valsts sabiedrības vēsturi, vispārējo, sociālo vēsturi? Vai tradicionālo zinātṇu vēstures konferenču ietvaros nebūtu organizējami atseviškām tēmām veltāmi speciāli, interdisciplināri mikrosimpoziji? Vai šie simpoziji nav organizējami pēc iepriekšējas domu apmaiņas? Vai zinātnieku jēdzienā nebūtu iekḷaujami arī izgudrotāji, intelektuālā ipašuma problēmas? Droši vien var uzdot vēl daudz līdzịgu jautājumu, tomēr gribētos izsacìt optimistisku prognozi, ka nedz pirms 50 gadiem aizsāktā konferenču tradīcija, nedz arī Baltijas vienotības ideja nav sevi izsmēlusi. Kaut gan Baltijas jēdzienu varbūt derētu paplašināt, ietverot tajā arī Baltijas jūras valstis - Ziemel̦valstis, Poliju, Vācijas ziemeḷus, arī Krieviju, Baltkrieviju, kā to darām Zinātṇu akadēmiju organizētajās Baltijas intelektuālās sadarbības konferencēs. Šo pirms kara 1935. gadā dzimušo tradīciju esam atdzīvinājuši 1999. gadā. Tagad šādas konferences notiek regulāri (Tallinā, Viḷnāā, Helsinkos, Rỉgā). Somi mūs aicina 


\section{J. Stradinš̌}

Pielikums 1. Baltijas zinātṇu vēstures konferences

\begin{tabular}{|c|c|c|c|c|}
\hline Nr. & Nosaukums & Datums, vieta & Tematiskā ievirze & $\begin{array}{c}\text { Ar konferenci saistītie } \\
\text { papildu pasākumi }\end{array}$ \\
\hline 1. & $\begin{array}{l}\text { Starprepublikāniskā ap- } \\
\text { spriede par dabaszinātṇu } \\
\text { un medicinas vēstures } \\
\text { pētniecības problēmām } \\
\text { Baltijā }\end{array}$ & $\begin{array}{l}\text { Rīga, 1958. g. } \\
6 .-7 . \text { jūn. }\end{array}$ & & \\
\hline 2. & $\begin{array}{l}\text { II Starprepublikāniskā } \\
\text { apspriede par Baltijas } \\
\text { zinātṇu vēsturi }\end{array}$ & $\begin{array}{l}\text { Tartu, 1959. g. } \\
\text { 20.-21. janv. }\end{array}$ & & \\
\hline 3. & $\begin{array}{l}\text { III Starprepublikāniskā } \\
\text { Baltijas dabaszinātṇu un } \\
\text { tehnikas vēstures konfer. }\end{array}$ & $\begin{array}{l}\text { Viḷna-Kauņa, } \\
\text { 1959. g. } \\
\text { 30. nov.-2. dec. }\end{array}$ & & \\
\hline 4. & $\begin{array}{l}\text { IV Starprepublikāniskā } \\
\text { konference par zinātṇu } \\
\text { vēsturi Baltijā }\end{array}$ & $\begin{array}{l}\text { Riga, 1962. g. } \\
\text { 27.-29. nov. }\end{array}$ & $\begin{array}{l}\text { Baltijas zinātnuu centri } \\
\text { Krievijas zinātnes sis- } \\
\text { tēmā 18.-20. gs. (RPI } \\
\text { simtgadei veltìtas } \\
\text { sekciju sēdes) }\end{array}$ & $\begin{array}{l}\text { Simpozijs "Pirmo } \\
\text { baktereologisko iestāžu } \\
\text { loma mikrobiologijas } \\
\text { un epidemiologijas } \\
\text { attīstība Krievijā" }\end{array}$ \\
\hline 5. & $\begin{array}{l}\text { V Konference par zi- } \\
\text { nātṇu vēsturi Baltijā }\end{array}$ & $\begin{array}{l}\text { Tartu, 1964. g. } \\
\text { 18.-21. jūn. }\end{array}$ & & \\
\hline 6. & $\begin{array}{l}\text { VI Starprepublikāniskā } \\
\text { konference par } \\
\text { dabaszinātṇu un } \\
\text { tehnikas vēsturi Baltijā }\end{array}$ & $\begin{array}{l}\text { Vil̦ņa, 1965. g. } \\
\text { 26.-27. okt. }\end{array}$ & & \\
\hline 7. & $\begin{array}{l}\text { VII Baltijas Zinātñu } \\
\text { vēstures konference }\end{array}$ & $\begin{array}{l}\text { Rìga, 1968. g. } \\
\text { 11.-13. dec. }\end{array}$ & $\begin{array}{l}\text { Baltijas vidutāiloma } \\
\text { sakaru veidošanā } \\
\text { starp Krieviju un Rie- } \\
\text { tumiem 17.-20. gs. }\end{array}$ & \\
\hline 8. & $\begin{array}{l}\text { VIII Baltijas Zinātnuu } \\
\text { vēstures konference }\end{array}$ & $\begin{array}{l}\text { Tartu 1970. g. } \\
\text { 1.-3. jül. }\end{array}$ & & \\
\hline 9. & $\begin{array}{l}\text { IX Baltijas Dabaszinātṇu } \\
\text { un tehnikas vēstures } \\
\text { konference }\end{array}$ & $\begin{array}{l}\text { Vil̦na, 1972. g. } \\
\text { 2.-4. nov. }\end{array}$ & & $\begin{array}{l}\text { Izbraukuma sēde Ge- } \\
\text { dučos, veltîta T. Gro- } \\
\text { thusam }\end{array}$ \\
\hline 10. & $\begin{array}{l}\text { X Baltijas Zinātñu } \\
\text { vēstures konference }\end{array}$ & $\begin{array}{l}\text { Rīga-Jelgava, } \\
\text { 1975. g. } \\
\text { 21.-23. apr. }\end{array}$ & $\begin{array}{l}\text { Pēterburgas ZA } \\
250 \text { gadi un tās } \\
\text { ietekme Baltijā. Jelga- } \\
\text { vas Academia Petrina } \\
200 \text { gadi }\end{array}$ & $\begin{array}{l}\text { Izbraukuma sēde } \\
\text { Jelgavā }\end{array}$ \\
\hline 11. & $\begin{array}{l}\text { XI Baltijas Zinātnes } \\
\text { un tehnikas vēstures } \\
\text { konference }\end{array}$ & $\begin{array}{l}\text { Tallina-Tartu, } \\
\text { 1977. g. } \\
\text { 18.-21. okt. }\end{array}$ & $\begin{array}{l}\text { Tartu Universitā- } \\
\text { tes atjaunošanas } \\
175 \text { gadu atcere }\end{array}$ & \\
\hline 12. & $\begin{array}{l}\text { XII Baltijas Zinātnes } \\
\text { un tehnikas vēstures } \\
\text { konference }\end{array}$ & $\begin{array}{l}\text { Vil̦ņa, 1979. g. } \\
\text { 23.-26. okt. }\end{array}$ & $\begin{array}{l}\text { Viḷnas Universitātes } \\
400 \text { gadu dibināšanas } \\
\text { jubileja }\end{array}$ & \\
\hline
\end{tabular}


Baltijas zinātṇu vēstures konferences pusgadsimta gaitā

\begin{tabular}{|c|c|c|c|c|}
\hline Nr. & Nosaukums & Datums, vieta & Tematiskā ievirze & $\begin{array}{c}\text { Ar konferenci saistītie } \\
\text { papildu pasākumi }\end{array}$ \\
\hline 13. & $\begin{array}{l}\text { XIII Baltijas Zinātņu } \\
\text { un tehnikas vēstures } \\
\text { konference }\end{array}$ & $\begin{array}{l}\text { Tartu, 1982. g. } \\
\text { 17.-19. nov. }\end{array}$ & $\begin{array}{l}\text { Tartu Universitātes } \\
\text { dibināšanas } 350 \text { gadu } \\
\text { atcere }\end{array}$ & \\
\hline 14. & $\begin{array}{l}\text { XIV Baltijas Zinātnuu } \\
\text { vēstures konference }\end{array}$ & $\begin{array}{l}\text { Jūrmala-Rīga, } \\
\text { 1985. g. } \\
\text { 25.-28. febr. }\end{array}$ & $\begin{array}{l}\text { Zinātnisko kolektīvu } \\
\text { un zinātnisko skolu } \\
\text { folkloras tapšana } \\
\text { Baltijā (rīkotājs - } \\
\text { Organiskās sintēzes } \\
\text { institūts) }\end{array}$ & $\begin{array}{l}\text { 1. Agrīno zinātnisko } \\
\text { priekšstatu veidošanās } \\
\text { (pēc arheologijas } \\
\text { datiem), veltīta Kr. } \\
\text { Barona } 150 \text { g. jubilejai } \\
\text { (Jūrmalā). 2. Zinātnes } \\
\text { un tehnikas pieminekḷi } \\
\text { (Rīgā) }\end{array}$ \\
\hline 15. & $\begin{array}{l}\text { XV Baltijas Zinātn̦u } \\
\text { un tehnikas vēstures } \\
\text { konference }\end{array}$ & $\begin{array}{l}\text { Rīga, 1987. g. } \\
\text { 29. sept.- } \\
\text { 1. okt. }\end{array}$ & $\begin{array}{l}\text { Rīgas Politehniskā } \\
\text { institūta dibināšanas } \\
125 \text { gadu atcere }\end{array}$ & \\
\hline 16. & $\begin{array}{l}\text { XVI Baltijas valstu } \\
\text { Zinātṇu vēstures } \\
\text { konference }\end{array}$ & $\begin{array}{l}\text { Vil̦na, 1991. g. } \\
\text { 4.-6. okt. }\end{array}$ & $\begin{array}{l}\text { Zinātnes vēsturiskā } \\
\text { pieredze Baltijas } \\
\text { republiku valstiskuma } \\
\text { atjaunošanā }\end{array}$ & \\
\hline 17. & $\begin{array}{l}\text { XVII Baltijas konference } \\
\text { par zinātṇu vēsturi }\end{array}$ & $\begin{array}{l}\text { Tartu, 1993. g. } \\
\text { 4.-6. okt. }\end{array}$ & $\begin{array}{l}\text { Zinātne Baltijā } \\
\text { starp Rietumiem un } \\
\text { Austrumiem }\end{array}$ & $\begin{array}{l}\text { Simpozijs kopā ar VFR } \\
\text { zinātṇu vēsturniekiem }\end{array}$ \\
\hline 18. & $\begin{array}{l}\text { XVIII Baltijas Zinātn̦u } \\
\text { vēstures konference }\end{array}$ & $\begin{array}{l}\text { Rìga, 1996. g. } \\
\text { 17.-19. janv. }\end{array}$ & $\begin{array}{l}\text { Zinātnes } \\
\text { funkcionēšana } \\
\text { lielvalstī un mazā } \\
\text { valstī: Baltijas } \\
\text { pieredze }\end{array}$ & $\begin{array}{l}\text { Paula Stradiṇa simt- } \\
\text { gadei veltīts simpozijs } \\
\text { "Medicīnas vēstur- } \\
\text { nieki - profesionāḷi un } \\
\text { amatieri" }\end{array}$ \\
\hline 19. & $\begin{array}{l}\text { XIX Baltijas Zinātņu } \\
\text { vēstures konference }\end{array}$ & $\begin{array}{l}\text { Viḷna-Kauņa, } \\
\text { 1999. g. } \\
\text { 15.-17. janv. }\end{array}$ & & \\
\hline 20. & $\begin{array}{l}\text { XX Baltijas Zinātṇu } \\
\text { vēstures konference }\end{array}$ & $\begin{array}{l}\text { Tartu, 2001. g. } \\
\text { 30.-31. janv. }\end{array}$ & & \\
\hline 21. & $\begin{array}{l}\text { XXI Baltijas Zinātņu } \\
\text { vēstures konference }\end{array}$ & $\begin{array}{l}\text { Rìga, 2003. g. } \\
\text { 13.-15. okt. }\end{array}$ & & $\begin{array}{l}\text { V. Ostvalda } 150 \text { gadu } \\
\text { jubileja, P. Valdena } \\
\text { piemiňas zīmes } \\
\text { atklāšana }\end{array}$ \\
\hline 22. & $\begin{array}{l}\text { XXII Baltijas Zinātņu } \\
\text { vēstures konference }\end{array}$ & $\begin{array}{l}\text { Viḷna-Kauņa, } \\
\text { 2006. g. } \\
\text { 5.-6. okt. }\end{array}$ & & \\
\hline 23. & $\begin{array}{l}\text { XXIII Baltijas Zinātņu } \\
\text { vēstures konference }\end{array}$ & $\begin{array}{l}\text { Rīga, 2008. g. } \\
\text { 9. -10. okt. }\end{array}$ & $\begin{array}{l}\text { Veltita Baltijas valstu } \\
\text { neatkarības iedibi- } \\
\text { nāšanas } 90 \text { gadiem } \\
\text { un Baltijas zinātñu } \\
\text { vēstures konfereču } \\
\text { tradīcijas } 50 \text { gadiem }\end{array}$ & $\begin{array}{l}\text { K. Arona piemiņas } \\
\text { sēde, Paula Stradiṇa } \\
\text { piemiņas sēde }\end{array}$ \\
\hline
\end{tabular}


2010. gadā piedalīties viṇu organizētajā Ziemeḷvalstu zinātṇu un ideju vēstures simpozijā, ir aizsāktas īpašas Eiropas zinātṇu vēstures konferences (4. šāda konference notikusi 2008. gada oktobrī Austrijā). Iespēju ir daudz, tās jāṇem vērā. Nobeigumā es gribētu atgādināt dižā latviešu dzejnieka un domātāja Raiṇa vārdus: "Pastāvēs, kas pārvērtīsies".

\section{2. pielikums}

1991. gada 13. janvārī, kad agonizējošās PSRS militāristi vērsās pret Lietuvas tautu tās neatkarības centienos ar bruņotu spēku un Viļ̦nas TV un radio bija spiesti pārtraukt darbību, Baltijas Zinātṇu vēstures un filozofijas asociācijas prezidents J. Stradiņš ar Latvijas Radio starpniecību sniedza visu triju valstu zinātnieku vārdā latviešu, krievu un angḷu valodā paziṇojumu par Baltijas solidaritāti centienos atjaunot neatkarību. Tā bija pirmā, momentānā reakcija uz Lietuvas notikumiem. Latvijas Zinātṇu akadēmija, institūti un augstskolas kritiskajā situācijā publiskus paziņojumus sniedza vēlāk, tādēḷ šis paziņojums pirmais pauda plašākai pasaulei Baltijas zinātnieku vairākuma viedokli. Tās bija dienas, kad no Rīgas skanēja pārraides arī lietuviešu valodā, kas tika translētas uz Lietuvu un arī ārzemēm. Taču 16. Baltijas Zinātṇu vēstures konference Viḷnā un Kauṇā notika paredzētajā laikā - 1991. gada oktobrī, un tas savukārt bija pirmais neatkarību atguvušo Baltijas valstu kopējais zinātnieku saiets.

\section{Paziņojums 13. I 91.}

Baltijas Zinātṇu vēstures un filozofijas asociācijas vārdā, kas apvieno apmēram 500 ievērojamu Lietuvas, Latvijas un Igaunijas zinātnieku un novadpētnieku, es kā šìs asociācijas prezidents visu triju valstu zinātnieku vārdā uzskatu par nepieciešamu sniegt šādu paziņojumu.

Ar dziḷu satraukumu un sāpēm esam uzṇēmuši ziṇas par aizvadītās nakts notikumiem Lietuvā. Mēs solidarizējamies ar Lietuvas tautu, ar visiem mūsu kolēgeiem un tuviem draugiem Lietuvā viṇu cīṇā par valstisko neatkarību un demokrātiju, izsakām dziḷu lìdzjūtību upuru piederīgajiem. Zinātne var attīstīties tikai demokrātijas attīstības apstākḷlos; mūsu tautu tradīcijas, mentalitāte, pēdējo gadu miermīlīgā attīstības gaita Baltijā ir kīla mūsu attīstības demokrātiskai gaitai. Reakcija un militārā diktatūra Padomju Savienībā nespēj atrisināt nevienu problēmu, tā var atsviest šo milzu valsti un visu pasauli aukstajā karā, regresā un stagnācijā.

Mēs pašreiz gatavojamies XVI Baltijas Zinātṇu vēstures konferencei, kurai šogad bija jānotiek Viḷnā un Kauṇā un kuras temats ir "Zinātne Baltijā, vēsturiskā pieredze un neatkarīgu valstu veidošanas perspektīva". Pašreiz mēs nezinām, vai konference notiks paredzētajā laikā, taču esmu dziḷi pārliecināts, ka agrāk vai vēlāk 
mūsu tikšanās notiks, ka mūsu valstis būs brīvi un cienījami locekḷi Eiropas un pasaules nāciju saimē.

Griežos pie Starptautiskās zinātṇu vēstures un filozofijas savienības, pie Starptautiskās Zinātṇu vēstures akadēmijas Parīzē, pie Vācu Dabaspētnieku akadēmijas "Leopoldina", pie daudzajiem kolēégiem zinātniekiem, ar kuriem mūs saista sadarbība - Maskavā, L̦eṇingradā, Kijevā, Minskā, Vācijā, Šveicē, Zviedrijā, Polijā, Čehoslovākijā, Rumānijā, Amerikas Savienotajās Valstīs, Kanādā, Dānijā -, būt šajā izškirīgajā vēstures brīdī ar Baltiju. Vēsturi raksta ne tikai institūtos un kabinetos, bet arī tautu nacionālajās un demokrātiskajās kustībās.

Cienijamie kolēǵi! Saprotam, ka Baltijas demokrātijas nākotne ir arī Padomju Savienības demokrātijas nākotne, tā savā ziṇā ir visas pasaules nākotne - vai mūs gaida labvēlīgi, harmoniski attīstības gadi, vai izolacionisms un tumsība. Baltija gadsimtu gaitā ir bijusi vienotājposms starp Vāciju un Krieviju, starp Skandināviju un Krieviju. Mēs ceram, ka šì saite nepārtrūks un ka šajā likteņstundā jūs atbalstīsiet mūsu miermīlīgos un demokrātiskos centienus.

Prof. Jānis Stradiņš,

Baltijas Zinātñu vēstures un filozofijas asociācijas prezidents

(publicēts pēc rokraksta latviešu valodā no J. Stradiña personiskā arhìva)

\section{3. pielikums}

Latvijas Zinātñu vēstures asociācijas Goda biedri

1. Dr. habil. Tālivaldis Vilciņš (1922-1997)

2. Dr. Ilgars Grosvalds

3. Dr. Aleksis Anteins (1915-2002)

4. Dr. h. c. eng. Jānis Klētnieks

5. Dr. Sigizmunds Timšāns (1931-2007)

6. Prof. Lu Yang Shang, Kīnas Nacionālās Zinātņu akadēmijas prezidents, Kīnas

Zinātṇu vēstures asociācijas prezidents

7. Dr. h. c. Jūlijs Jākobsons

8. Prof. Dr. Jāzeps Ločmelis, LZA goda loceklis
2002

Apstiprināšanas gads

1997

1997

2001

2001

2001

2002

2002 
9. Prof. Dr. Juozs Algimants Krikštopaitis (Lietuva) 2002

10. Prof. Dr. Karls Sïlivasks, Igaunijas ZA ìstenais loceklis 2002

11. Prof. Dr. habil. chem., Dr. hist. h. c. Jānis Stradiņ̌̌ 2002

12. Dr. h. c. Kārlis Ēriks Arons (1933-2005) 2003

13. Prof. Dr. habil. Arnis Vīksna, LZA īstenais loceklis 2006

14. Eng. Arturs Zalsters (1929 - 2008) 2006

15. Prof. Dr. Imants Meirovics 2006

16. Prof. Dr. habil. Ivars Knēts, LZA īstenais loceklis 2008

17. Dr. Haino Tanklers (?-2008) (Igaunija) 2008

18. Prof. Dr. Liberts Klimka (Lietuva) 2008

19. Grētele Brauere (1918-2008), Vilhelma Ostvalda mazmeita (Vācija) 2008

20. Prof. Dr. Juris Upatnieks, LZA ārzemju loceklis, hologrāijas izgudrotājs (ASV/Latvija) 2008

21. Prof. Emeritus Dr. Jānis Lielmežs 2008 (Kanāda, Vankūvera) 2008

22. Prof. Dr. habil. phys. Mārcis Auzin̦š, LZA īstenais loceklis 2009

23. Prof. Dr. habil. phys. Juris Zaḳis, LZA ìstenais loceklis 2009

24. Prof. Dr. habil. hist. Heinrihs Strods, LZA goda loceklis 2009

25. Dr. Uldis Alksnis, docents 2009 


\section{Vēres}

1. Stradiņš J. Latvijas Zinātṇu vēstures asociācijas pirmsākumi un organizētas zinātṇu vēstures pētniecības 50 gadi Baltijā.//Latvijas Universitātes Raksti. 738. sēj. Zinātnu vēsture un muzejniecība. 2008

2. Daṇilevskis V. Krievu tehnika. Rìga: LVI, 1950. 708 lpp.

3. Каминер Л. В., Поляков И. А. Международные объединения по истории науки.//Вопросы истории естествознания и техники (ВИЕТ). Москва: АН СССР, 1956, вып. 2, с. 326-335.

4. Григорьян А. Т. Первая конференция Советского Национального объединения истории естествознания и техники.//Boпросы истории естествознания и техники (ВИЕТ), Москва: АН СССР, 1957, вып. 3, с. 264-267.

5. Протокол №4/400 заседания Президиума АН Латв ССР от 30 января 1958. г. LZA Arhivs, 1. f., 1. apr., 1. 1.

6. Страдынь Я. Петр Иванович Валескалн (1899-1987).//Из истории естествознания и техники Прибалтики. Т. 8. Рига: 1991, с. 223-225; Akadēmiķis Pēteris Valeskalns. Biobibliogrāfija. Rīga: Zinātne, 1969. 67 lpp.

7. Stradin̦š J. Nodibināta Latvijas dabaszinātṇu un tehnikas vēsturnieku grupa. Rigas Balss, Nr. 128, 1958.2.VI.

8. Stradiņš J. Dabas zinātṇu un tehnikas vēsturnieku nacionālā grupa. Latvijas Zinātnieks, Nr. 13, 1958.18.VI.

9. Stradiṇš J. Paula Stradiṇa Medicinas vēstures muzeja tapšana un izveidošanās.// Acta Medico-Historica Rigensia. Vol. 8 (27). Rìga: 2007, 31.-116. lpp.

10. Stradiņš J. Profesora Paula Stradin̦a programmatiskais referāts Latvijas medicīnas vēsturē un tā ideju tālākattīstība.//Acta Medico-Historica Rigensia. Vol. 8 (27). Rìga: 2007, 117. lpp.; Acta Medico-Historica Rigensia. Vol. 8 (27). Rīga: 2007, 130. lpp. (N. Figurovska vēstule P. Stradiṇam: 128.129. lpp.)

11. Страдынь П. И. Медицина Прибалтики XVI-XIX веков как связующее звено между медициной Запада и русской медициной//Страдынь П. И. Избранные труды. Т. 3. Рига: Зинатне, 1965, с. 358-368.

12. Vìksna A. Pauls Stradiñš, 1896-1996. Nepublicēti dokumenti un materiāli. Latvijas Ārsts, Nr. 1, 1996, 50.-76. lpp. (P. Stradiņa vēstule P. Valeskalnam).

13. Magone J. Pirmā Dabaszinātnieku un medicinas vēsturnieku apspriede. Latvijas PSR ZA Vēstis, Nr. 7, 1958, 159. lpp.

14. Страдынь Я. Межреспубликанское совещание ученых Прибалтики по проблеме изучения истории естественных наук и медицины. Известия АН Латв. ССР, № 8, 1958, с. 153-156; Из истории медициньы. Рига, 1959, т. 2, с. 309-313 (ar konferences rezolūcijas pilnu tekstu).

15. Страдынь П. И., Страдынь Я. П. Некоторые проблемы изучения истории науки в Прибалтике//Из истории медицины. Т. 2. Рига: 1959, c. $263-273$. 
16. Stradiņ̌̌ J. Etīdes par Latvijas zinātņu pagātni. Rīga: Zinātne, 1982. 395 lpp. (Par Latvijas Zinātṇu vēstures asociāciju un Baltijas konferencēm: 263.278. lpp.)

17. Аннотированный список конференций историков науки Прибалтики (1958-1985). Сост. К. Г. Васильев, Я. П. Страдынь, В. В. Калнин, У. В. Пальм. Тарту: 1986. 138 с.

18. Страдынь П.И., Страдынь Я. П. Работа по изучению истории науки в Латвии.//Вопросы истории естествознания и техники (ВИЕТ). Москва: АН СССР, 1959, вып. 8, с. 184-186.

19. Stradiṇš J. Baltijas valstu Zinātṇu vēstures un filozofijas asociācijas un Baltijas medicīnas vēstures asociācijas nodibināšana. Latvijas PSR ZA Vēstis, Nr. 7, 1991, 132.-134. lpp.

20. Stradiņš J. Akadēmiskā Dzīve. 33. rakstu krājums. Rīga: 1991, 72.-75. lpp.; par šìs asociācijas dibināšanu arī îsa informācija: Bonpocbı uсторuu естествознания и техники (ВИЕТ), № 3, 1991, с. 168.

21. Siilivask K. АГOPA [Baltic Conferences on History of Sciences, japāṇu valodā]. Kagasuki Kenkyn (Journal of History of Science, Japan), Vol. 40 (No 217), 2001, Spring, pp. 50-52.

22. Krikštopaitis J.Al. Activities of historians of science in the Baltic States. Newsletter of the International Union of the History and Philosophy of Science, New Series, No 2, 2004, November, pp. 15-16.

23. Nova Miscellanea Historiae Scientiarum Baltica - 50. Rīga: RTU, 2008. 107 lpp.

24. Страдынь Я. Работа латвийских историков науки за 1958-1967 гг. (10 лет деятельности Латвийского объединения историков естествознания и техники).//Из истории естествознания и техники Прибалтики. Т. 1. Рига: 1968, с. 269-272.

25. Stradiņš J. Latvijas zinātṇu vēstures pētijumi, Latvijas zinātnisko tradīciju apzināšana un uzturēšana (1987-1992).//Acta Historiae Scientiarum Baltica. Vol. 9. Rīga: 1992, 269.-280. lpp.

26. Stradiņš J. Veikums Latvijas zinātṇu vēstures izpētē pēdējos gados (19961997).//Acta Medico-Historica Rigensia. Vol. 3 (22). Rigga: 1997, 385.394. lpp.

27. Stradiṇš J. Latvijas zinātṇu vēstures izpēte 1997.-1999. gadā.//Acta MedicoHistorica Rigensia. Vol. 5 (24). Rīga: 2000, 383.-392. lpp.

28. Stradinšs J. Pētijumi Latvijas zinātṇu vēsturē pēdējos trijos gados (2000-2002).// Acta Medico-Historica Rigensia. Vol. 6 (25). Rìga: 2002, 349.-364. lpp.

29. Grosvalds I., Klētnieks J. Latvijas Zinātṇu vēstures asociācijai - 45.//RTU Zinātniskie Raksti. 8. sēr. Zinātņu un augstskolu vēsture. 5. sēj. Rīga: 2004, 67.-70. lpp. 
30. Stradiņš J. Latvijas zinātṇu, medicinas un tehnikas vēstures izpēte pēdējos gados (2003-2005).//Acta Medico-Historica Rigensia. Vol. 8 (27). Rìga: 2007, 392.-406. lpp.

31. Stradiṇš J. Veikums Latvijas zinātṇu, medicīnas un tehnikas vēstures apzināšanā pēdējos gados (2003-2005).//RTU Zinātniskie Raksti. 8. sēr. 9. sēj. Rīga: 2006, 138.-147. lpp.

32. Stradiṇš J. Baltijas zinātṇu vēstures konferenču 50 gadi: 1958-2008.//RTU Zinātniskie Raksti. 8. sēr. Humanitārās un sociālās zinātnes. Zinātṇu un augstskolu vēsture. 15. sēj. Rīga: 2009, 9.-25.lpp.

33. Stradiṇš J. 23. Starptautiskā Baltijas zinātṇu konference.//RTU Zinātniskie Raksti. 8. sēr. Humanitāras un sociālās zinātnes. Zinātņu un augstskolu vēsture. 15. sēj. Rīga: 2009, 106.-116. lpp. (Pielikumā: Baltijas zinātṇu vēstures un filozofijas generālās asamblejas sēdes protokols. Rīgā, 2008.10.X)

\section{0 years of the Baltic Conferences on the History of Sciences: 1958-2008 (Summary)}

\section{By Jānis Stradiņ̌̌}

The beginnings and evolution organized science history studies in the Baltics have been reviewied. Due to the efforts of Prof. Pauls Stradiņš (1896-1958), a Latvian medical scientist and founder of the Museum of History of Medicine in Riga, the first Baltic conference on the history of natural sciences and medicine has been held in Rìga on June, 6-7, 1958. Participants in this firt conference from Lithuanian side were Prof. Slavenas, V. Girdzijauskas, S. Biziulevičus, from Estonian side - V. Kalnins and K. Villako. A common Baltic coordination commission on the history of sciences has been founded, which functioned oficially until 1965, later - in the framework of Soviet National Association of History of Natural Sciences and Technology (a part of IUHPS), where Estonian, Latvian and Lithuanian branches (in fact, separated national associations) have been organized. Association has been founded in May, 1958 (chairman - Prof. P. Valeskalns, 1958-1987, Prof. J. Stradiňš - since 1987). The Estonian Association has been headed by Prof. F. Klement, the Lithuanian Association - by Prof. P. Slavenas.

Since 1958 conferences on the history of sciences became a tradition. 23 conferences have been held in Tartu, Vilnius, Kaunas, Tallinn, Rìga, Jelgava and Jürmala during 50 years (before the regain of independence - 15 conferences). In October 1990 in Riga the Association of History and Philosophy of Sciences of the Baltic 


\section{J. Stradiņš}

States has been founded (copresidents - from Lithuania Prof. J. A. Krikštopaitis, from Latvia - Prof. J. Stradiņš, from Estonia - Prof. K. Siilivask, till 2006, Prof. J Aaviksoo, since 2006). On 13 January, 1991 the Association gave a message to the scientific world in favour of the independence of Lithuania, condemning the brutal attack of Soviet military forces in Vilnius. These events have been signs of solidarity and intellectual resistence of the Baltic scientists against Soviet centralization, for keeping regional identity of the Baltics.

4-6 October, 1991 the 16th Conference took place in Vilnius as a first common conference of scientists of the independent Baltic States. Eight conferences more have been organized with the participation of historians of science from Germany, Finland, Poland, Russia, Ukraine, USA, Great Britain, Japan, Belgium, France, Byelorussia, etc), and they remain a traditional element of the Baltic cooperation. The future of these conferences as well as the problem of lingua franca have been discussed.

Jānis Stradiň̦̌, profesors, Dr. habil. chem., Dr. hist. h. c. stradins@lza.lv 